\title{
Characterization of Secondary Metabolites from Rhizopus oryzae and Its Effect on Plant Pathogens
}

\author{
Mohammed Faisal Peeran ${ }^{*}$, Lakshman Prasad ${ }^{2}$ and Deeba Kamil ${ }^{2}$ \\ ${ }^{1}$ ICAR-Indian Institute of Spices Research, Regional Station, Appangala, Madikeri, \\ Karnataka - 571 201, India \\ ${ }^{2}$ ICAR-Indian Agricultural Research Institute, Pusa campus, New Delhi-110012, India \\ *Corresponding author
}

\section{A B S T R A C T}

\begin{tabular}{|l|}
\hline K e y w o r d s \\
$\begin{array}{l}\text { Rhizopus oryzae, Methyl } \\
\text { euginol, Alternaira, } \\
\text { Pythium, Phoma and } \\
\text { Rhizoctonia }\end{array}$ \\
\hline Article Info \\
\hline $\begin{array}{l}\text { Accepted: } \\
\text { 07 February } 2018 \\
\text { Available Online: } \\
\text { 10 March } 2018\end{array}$ \\
\hline
\end{tabular}

\section{Introduction}

Fungal secondary metabolites are low moelcualr weight, heterogeneous group of natural compounds mainly functioning on survival of the organsim under stress conditions, and also responsible for competition, symbiosis, metal transport, and differentiation (Demain and Fang, 2000). Apart from it, the compounds also used for medical, pharmaceutical, or agricultural purposes (Calvo et al., 2001). This group includes antibiotics, of natural origin, that are capable of inhibiting the microbial growth, of various microbes during the processes of development and sporulation (Stone and

\begin{abstract}
Secondary metabolites plays a vital role during plant-fungal interaction, in addition to the synthesis of secondary metabolites, several fungal species also have antifungal effects on other microbes. In the present study secondary metabolites of three different isolates of Rhizopus oryzae were extracted and screened for their antifungal properties against Alternaira, Pythium, Phoma and Rhizoctonia at $500 \mathrm{ppm}$. The isolate $R$. oryzae (15) showed maximum inhibition against $R$. solani $(81.53 \%)$. GC/MS analysis of the secondary metabolites in $R$. oryzae (6975) revealed the presence of Benzene, 1,2dimethoxy-4-(2-propenyl) commonly known as methyl euginol which might be compounds containing benzene and higher fatty acids group.
\end{abstract}


aphanidermatum, Rhizoctonia solani and Phoma lingum.

\section{Materials and Methods}

Fungal cultures belonging to Rhizopus oryzae, Alternaria alternata, Pythium aphanidermatum, Rhizoctonia solani and Phoma lingum were obtained from Indian Type Culture Collection (ITCC), Division of Plant Pathology, ICAR-IARI, New Delhi, India.

\section{Liquid culture and metabolite production}

Two 7-mm diameter plugs of $R$. oryzae obtained from actively growing margins of PDA cultures, were inoculated into $250 \mathrm{ml}$ conical flasks containing $100 \mathrm{ml}$ of sterile one-fifths strength potato dextrose broth (PDB). The stationary cultures were incubated for three weeks days at $25{ }^{\circ} \mathrm{C}$. The cultures were filtered through filter paper (Whatman No. 4; Brentford, UK).

Extraction of the metabolites from the liquid culture

The filtered culture broth (2L) of $R$. oryzae was extracted exhaustively with equal volume of ethyl acetate twice. The combined organic fraction was dried $\left(\mathrm{Na}_{2} \mathrm{SO}_{4}\right)$ and evaporated under reduced pressure at $35^{\circ} \mathrm{C}$ using rotary evaporator (Heidolph, Germany). The redbrown residue was recovered and further used for GCMS analysis.

\section{Antifungal assays}

The organic crude extracts and the chromatographic fractions were tested against A. alternata, $P$. aphanidermatum, $R$. solani and $P$. lingum for their antifungal properties. Pathogen plugs (9-mm diameter) from growing edges of the colonies were placed at the centre of petri dishes containing one-fifths the strength of PDA. Ten microlitre of the crude extracts were applied on the top of each plug. Plates were incubated at $25^{\circ} \mathrm{C}$ for 3 days. The pathogen growth was measured daily as colony diameter. Each treatment consisted of three replicates and the experiment was repeated twice.

\section{In vitro seed germination assay}

Isolates of $R$. oryzae were tested for the seed mitotic inhibitor activity by seedling vigour index by the standard roll towel method (ISTA, 1999). Twenty five mustard seeds treated with $500 \mathrm{ppm}$ were kept over the presoaked germination paper. The seeds were held in position by placing another presoaked germination paper strip and gently pressed. The butter paper sheets along with seeds were then rolled and incubated in growth chamber for 15 days. Two replications with 25 seeds each per replication, were maintained. Root length and shoot length of individual seedlings were measured and the germination percentage of seeds was recorded.

Vigour Index $=($ Mean root length + Mean shoot length) x Germination \%

\section{GC/MS analysis of volatile compounds}

The crude metabolites of $R$. oryzae (isolate 5) was analyzed through GC/MS (Thermo scientific Trace GC Ultra DSQ II) equipped with column $(30 \mathrm{~mm} \times 0.25 \mathrm{~mm} \times 0.25 \mu \mathrm{m})$ under the following conditions: carrier gas as Helium with flow rate at $1 \mathrm{ml}$ per minute and $1 \mu \mathrm{l}$ sample injection with pre injection of solvent by AI/AS 3000 Method; split-less mode injection with $30 \mathrm{sec}$ of sampling time; the column temperature maintained initially at $60^{\circ} \mathrm{C}$ at the rate of $5^{\circ} \mathrm{C} / \mathrm{min}$ and no hold was followed by increasing up to $240{ }^{\circ} \mathrm{C}$. It was kept at the same temperature for 8 minutes hold; the electron impact energy was $70 \mathrm{eV}$, Julet line temperature was set at $2000{ }^{\circ} \mathrm{C}$ and 
the source temperature was set at $200{ }^{\circ} \mathrm{C}$. Electron impact (EI) mass scan $(\mathrm{m} / \mathrm{z})$ was recorded in the 45-450 aMU range.

The total chromatogram was obtained for each sample. The base peak of each spectrum was compared with the base peak of the chemical components in the NIST Ver.2005 MS data library through on-line and the spectrum was compared through GC/MS for the identification of the secondary metabolites present in the crude toxin.

\section{Results and Discussion}

All filamentous fungi produce several low molecular weight bioactive compounds which are known as secondary metabolites. In fungi, the genes required for the biosynthesis of a secondary metabolite are clustered. $R$. oryzae produce ethanol, lactic acid, and fumaric acid in high quantities (Guo et al., 2010; Vially et al., 2010). Production of antimicrobial secondary metabolites has been reported in many fungal biocontrol agents (Sivasithamparam and Ghisalberti 1998; Vyas and Mathur 2002). However, in the present study four plant pathogens were screened with the secondary metabolites of three different $R$. oryzae isolates. The isolate $R$. oryzae (15) had the maximum inhibition against $R$. solani $(81.53 \%)$ followed by the same isolates against Pythium (50.00 \%) (Table 1 and Figure 1).

The ethyl acetate extract of the cell culture of $R$. oryzae exhibited significant antifungal activity against $R$. solani indicating that the metabolies are effective against those fungi which multiplies through mitosis. Sohail et al., (2014) showed that the extracts of $R$. stolonifer is quite effective in acetonitrile solvent as compared to results in n-hexane, minimum inhibitory concentration (MIC), of the extracts were in the range of $0.25 \mathrm{mg} / \mathrm{ml}$. Mitotic inhibition activity among the three isolates was tested on seedling of Brassica juncea, maximum reduction in seed vigour index was $51.61 \%$ with the isolate $R$. oryzae (isolate 15) as against untreated control. It was followed by $R$. oryzae (isolate 10) which indicates that the extract may contain herbicidal activity. However, further studies to isolate the bioactive compounds are required (Table 2 and Figure 2).

Table.1 In vitro antifungal activity of crude metabolites from $R$. oryzae

\begin{tabular}{|c|c|c|c|c|c|c|c|c|c|}
\hline \multirow[t]{2}{*}{$\begin{array}{l}\text { S. } \\
\text { No }\end{array}$} & \multirow[t]{2}{*}{ Isolate } & \multicolumn{2}{|c|}{$\begin{array}{c}\text { Pythium } \\
\text { aphanidermatum }\end{array}$} & \multicolumn{2}{|c|}{ Rhizoctonia solani } & \multicolumn{2}{|c|}{$\begin{array}{l}\text { Alternaria } \\
\text { alternata }\end{array}$} & \multicolumn{2}{|c|}{ Phoma lingum } \\
\hline & & $\begin{array}{c}\text { Radial } \\
\text { Growth } \\
\text { (cm) }\end{array}$ & $\begin{array}{c}\text { Inhibiti } \\
\text { on over } \\
\text { control } \\
(\%)^{*}\end{array}$ & $\begin{array}{c}\text { Radial } \\
\text { Growth } \\
\text { (cm) }\end{array}$ & $\begin{array}{c}\text { Inhibiti } \\
\text { on over } \\
\text { control } \\
(\%)^{*}\end{array}$ & $\begin{array}{l}\text { Radial } \\
\text { Growt } \\
\text { h (cm) }\end{array}$ & $\begin{array}{c}\text { Inhibiti } \\
\text { on over } \\
\text { control } \\
(\%)^{*}\end{array}$ & $\begin{array}{l}\text { Radial } \\
\text { Growt } \\
\text { h }(\mathrm{cm})\end{array}$ & $\begin{array}{c}\text { Inhibiti } \\
\text { on over } \\
\text { control } \\
(\%)^{*}\end{array}$ \\
\hline 1 & $R$. oryzae 5 & 3.65 & $3.94^{\mathrm{b}}$ & 1.05 & $67.69^{b}$ & 3.75 & $8.53^{b}$ & 4.2 & - \\
\hline 2 & R. oryzae 10 & 3.7 & $2.63^{\mathrm{b}}$ & 1.2 & $63.07^{b}$ & 3.7 & $9.75^{\mathrm{b}}$ & 4.2 & - \\
\hline 3 & R. oryzae 15 & 1.9 & $50.00^{\mathrm{a}}$ & 0.6 & $81.53^{\mathrm{a}}$ & 3.35 & $18.29^{\mathrm{a}}$ & 4.2 & - \\
\hline 4 & Control & 3.8 & & 3.25 & & 4.1 & & 4.2 & \\
\hline
\end{tabular}

* Mean of four replications 
Table.2 Effect of crude metabolites at $500 \mathrm{ppm}$ on the growth of mustard seeds

\begin{tabular}{|c|c|c|c|c|c|}
\hline S. No & $\begin{array}{c}\text { Isolates } \\
\text { No. }\end{array}$ & $\begin{array}{c}\text { Shoot length } \\
(\mathbf{c m}) *\end{array}$ & $\begin{array}{c}\text { Root } \\
\text { Length }(\mathbf{c m}) *\end{array}$ & $\begin{array}{c}\text { Reduction in } \\
\text { Germination }(\%)\end{array}$ & $\begin{array}{c}\text { Reduction in } \\
\text { vigour }(\%)\end{array}$ \\
\hline $\mathbf{1}$ & 5 & 7.53 & 18.18 & 88 & $13.97^{\mathrm{c}}$ \\
\hline $\mathbf{2}$ & 10 & 6.04 & 17.62 & 68 & $38.82^{\mathrm{b}}$ \\
\hline $\mathbf{3}$ & 15 & 5.23 & 15.98 & 60 & $51.61^{\mathrm{a}}$ \\
\hline
\end{tabular}

* Mean of twenty five mustard seeds in four replications

Table.3 Compounds identified from $R$. oryzae isolate 5 through GC/MS

\begin{tabular}{|l|l|l|}
\hline S. No. & RT & Name of the compound \\
\hline 1 & 28.028 & 1-(tert-Butyl)-3-cyclohexylcarbodi \\
\hline 2 & 31.963 & Phthalic acid, cycloheptyl ethyl ester \\
\hline 3 & 32.831 & Hexadecanoic acid \\
\hline 4 & 36.073 & $9,12-$ Octadecadienoic acid, methyl ester, \\
\hline 5 & 44.139 & Cyclodecasiloxane, eicosamethyl- \\
\hline 6 & 44.980 & Pentanoic acid \\
\hline 7 & 45.652 & 2,4-diphenyl-5-(p-methoxybenzoyl)- 1,2,3-triazole \\
\hline
\end{tabular}

Fig.1 In vitro screening of ethyl acetate extract metabolites on the Growth of the pathogen@ 500 ppm
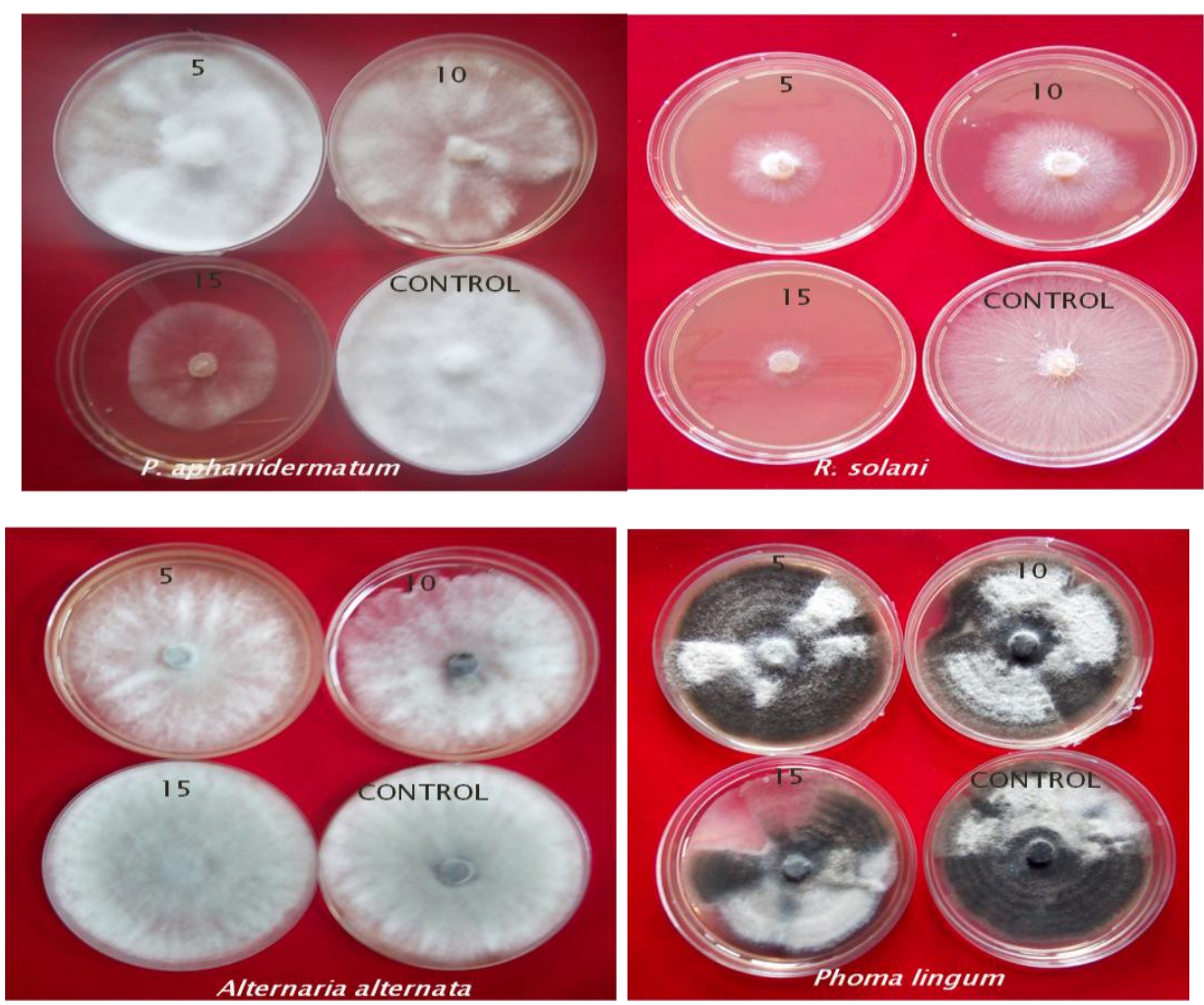
Fig.2 Effect of metabolites at 500 ppm on the growth of mustard seeds
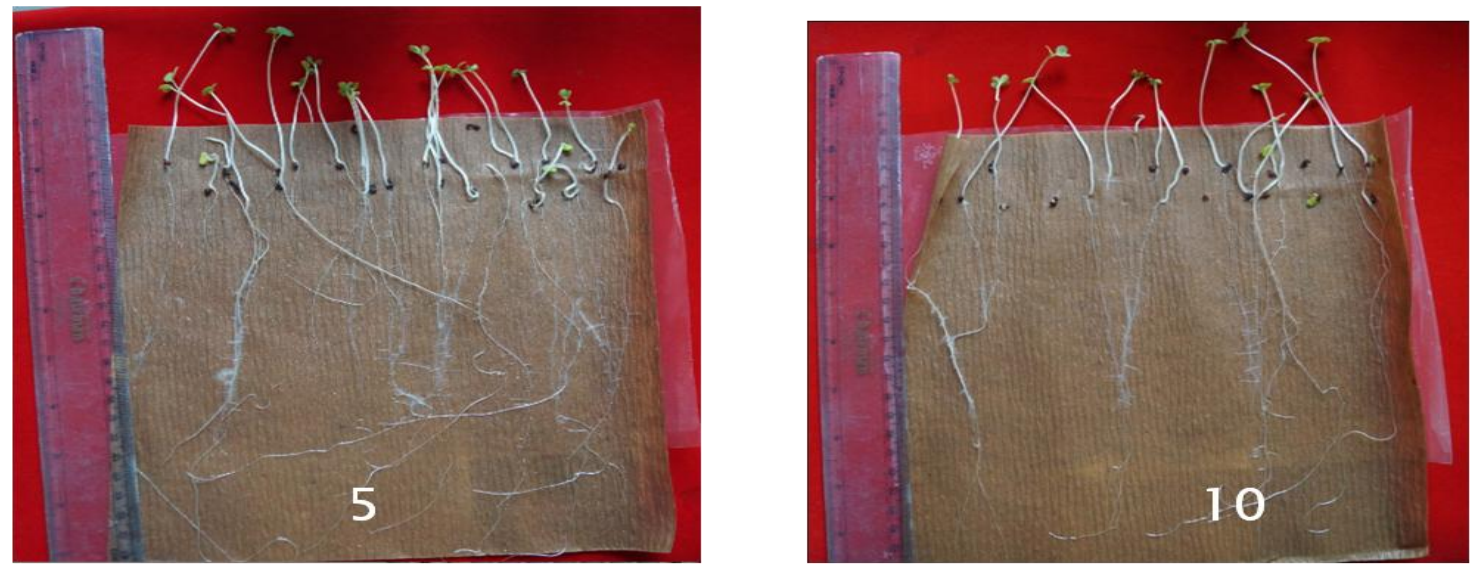

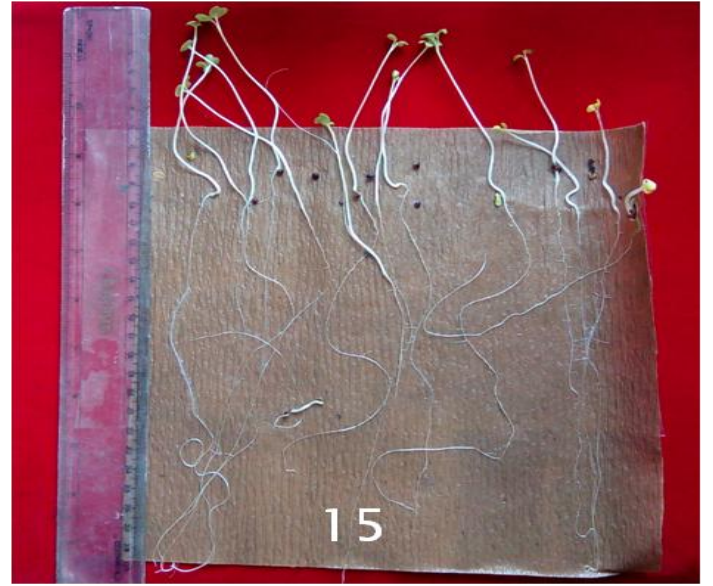

5, 10 and 15 stands for $R$. oryzae isolate number

It's not new that the $R$. oryzae produce a plethora of bioactive secondary metabolites drawing many a curious researcher to the tidal swamps. In the present study we also tried to identify the compounds responsible for the bioactivity against major pathogens. Some of the major peaks are having more abundance ratio as listed in Table 3. Interestingly several compounds containing benzene like Benzene, 1,2-dimethoxy-4-(2-propenyl) commonly known as methyl eugenol. Hence from the GC/MS profile, the antibiotic activity of the isolate may be due to the presence of benzene and thiol group based compounds. Methyleugenol and eugenol extracted form Piper diverticum were tested individually at

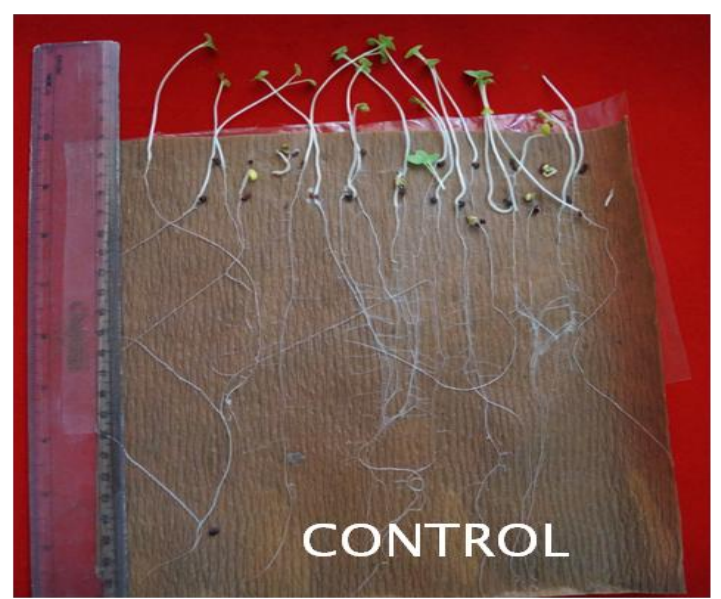

concentrations of 0.25 to $2.5 \mathrm{mg} / \mathrm{mL}$ against $F$. solani f. sp. piperis, and it expressed the strong antifungal index, from $18.0 \%$ to 100.0\% (da Silva et al., 2014). Eugenol and methyl eugenol are phenylpropanoids and are known to possess antimicrobial activity, induction of oxidative stress characterized by elevated levels of free radicals and an impaired antioxidant defence system. It may be a possible mechanism of cell death (Khan et al., 2011). In additions to antifungal activtity we have also reported for the first time that the existence of Methyl Euginol in Rhizopus oryzae (Faisal and Lakshman, 2016). 


\section{References}

Calvo, A.M., Gardner, H.W. and Keller, N.P. 2001. Genetic connection between fatty acid metabolism and sporulation in Aspergillus nidulans. Journal of Biological Chemistry. 276:25766 -25774.

Da Silva, J.K.R., Silva, J.R.A., Nascimento, S.B., da Luz, S.F.M., Meireles, E,N., Alves, C.N., Ramos, A.R. and Maia, J.G.S. 2014. Antifungal Activity and Computational Study of Constituents from Piper divaricatum Essential Oil against Fusarium Infection in Black Pepper. Molecules 19: 17926-17942.

Demain, A. and Fang La. 2000. The natural functions of secondary metabolites. Advances in Biochemical Engineering/Biotechnology. 69:1-39

Faisal, M.P. and Lakshman, P. 2016. A potential source of methyl eugenol from secondary metabolite of Rhizopus oryzae 6975. International Journal of Applied Biology and Pharmaceutical Technology 7: 187-192

Guo, Y., Yan, Q., Jiang, Z., Teng, C. and Wang, X. 2010. Efficient production of lactic acid from sucrose and corncob hydrolysate by a newly isolated Rhizopus oryzae GY18. Journal of Indian Microbiology and Biotechnology. 37:1137-1143.

Hadley, G. and Harrold. C. E. 1958. The sporulation of Penicillium notatum westling in submerged liquid cultures. Journal of Experimental Botany 9:418428.

Harman, G.E., Howell, C.R., Viterbo, A., Chet, I. and Lorito, M. 2004. Trichoderma species opportunistic, avirulent plant symbionts. Nature Reviews Microbiology. 2: 43-56.
Khan, A., Ahmad, A., Akhtar, F., Yousuf, S., Xess, I., Ahmad Khan, L. and Manzoor, N. 2011. Induction of oxidative stress as a possible mechanism of the antifungal action of three phenyl propanoids. FEMS Yeast Res. 11 (1): 114-122. doi: 10.1111/j.1567-1364.2010.00697.x.

Laila, P.., Partida-Martinez and Hertweck C. 2005. Pathogenic fungus harbours endosymbiotic bacteria for toxin production. Nature 437: 884-888

Mims, C. W., Richardson, E. A. and Timberlake. W. E. 1988. Ultrastructural analysis of conidiophore development in the fungus Aspergillus nidulans using freeze-substitution. Protoplasma 44:132141.

Sivasithamparam, K. and Ghisalberti, E, L. 1998. In: Kubicek, C.P., Harman, G.E. (eds) Trichoderma and Gliocladium, vol 1. Taylor and Francis, London, pp 139191.

Sohail., Afzal, M., Iqbal, Z., Sheena, Khan, S.M., Rahman, I., Khan, W., Asghar, A., Ullah, I., Numan, M. 2014. Antimicrobial activity of mycelial extracts of Rhizopus stolonifer against different fungal and bacterial pathogenic strains. International Journal of Biosciences 4(7):276-281

Stone, M.J. and Williams, D.H. 1992. On the evolution of functional secondary metabolites (natural products). Molecular Microbiology. 6(1): 29-34.

Vially, G., Marchal, R. and Guilbert N. 2010. L(+)-lactate production from carbohydrates and lignocellulosic materials by Rhizopus oryzae UMIP 4.77. World Journal of Microbiology and Biotechnology. 26:607-614.

Vyas, R.K. and Mathur, K. 2002. Trichoderma spp. in cumin rhizosphere and their potential in suppression of wilt. Indian Phytopathology. 55:455-45

\section{How to cite this article:}

Mohammed Faisal Peeran, Lakshman Prasad and Deeba Kamil. 2018. Characterization of Secondary Metabolites from Rhizopus oryzae and Its Effect on Plant Pathogens. Int.J.Curr.Microbiol.App.Sci. 7(03): 705-710. doi: https://doi.org/10.20546/ijcmas.2018.703.082 